\title{
Analisa dan Perancangan Sistem Rekrutmen Online (E-Recruitment) Berbasis Web pada PT Bravo Security Indonesia
}

\author{
Ivan Royanto Hutabarat dan Jay Idoan Sihotang \\ Fakultas Teknologi Informasi, Universitas Advent Indonesia
}

\begin{abstract}
Abstrak
Pada era globalisasi ini kebutuhan akan rasa aman semakin meningkat, selain keamanan data atau informasi namun juga rasa aman secara fisik, oleh karena itu jasa satpam masih dibutuhkan untuk memberi penjagaan terhadap tempat atau daerah tertentu. Pada kasus ini PT. Bravo Security Indonesia sebagai perusahaan penyalur satpam, membutuhkan banyak calon satpam agar bisa di pekerjaan ke berbagai instansi publik atau swasta.Tujuan penelitian ini adalah untuk merancang sebuah sistem rekrutmen yang berbasis Online yang dapat digunakan oleh pelamar dan juga bagian departemen personalia di perusahaan PT. Bravo Security Indonesia. Analisa dan perancangan yang diharapkan ialah, dapat menganalisis kebutuhan informasi atau data untuk proses rekrutmen yang ditujukan terhadap calon satpam yang ingin melamar di perusahaan ini. Perancangan menggunakan model waterfallyang pemodelannya membutuhkan Analisa Kebutuhan ( Recruitment Analisis), Desain Sistem (System Design), Pembuatan Kode Program (Coding), Penerapan dan Pengujian (Testing), serta Pendukung dan Pemeliharaan (Support and Maintenance). Hasil berupa sebuah sistem rekrutmen online yang dikhususkan untuk departemen personalia, karna personalia akan memiliki informasi yang dibutuhkan agar dapat menilai pelamar sebelum mereka dipanggil untuk lanjut ke sesi wawancara langsung. Selain untuk mempermudah proses rekrut satpam, sistem ini juga diharapkan dapat membuat pendataan terhadap anggota baru satpam lebih mudah dan terintegrasi dengan sistem, serta saran untuk kedepanya ialah, sistem dapat dikembangkan untuk merekrut pegawai yang lain selain satpam.
\end{abstract}

Kata-kata kunci: e-recruitment, rekrutmen Online berbasis Website.

\section{Analysis and Design of Web Based Online Recruitment System (E- Recruitment) at PT Bravo Security Indonesia}

In this globalization era, the need for security is increasing, in addition to data or information security but also a sense of physical security, therefore security guard services are still needed to protect certain places or regions. In this case, PT. Bravo Security Indonesia as a security guard distributor company, requires many prospective security guards to be able to work in various public or private agencies. The purpose of this study is to design an online-based recruitment system that can be used by applicants as well as the personnel department at PT. Bravo Security Indonesia. The expected analysis and design is to be able to analyze the information or data requirements for the recruitment process aimed at prospective security guards who want to apply for this company. The design uses the waterfall model, whose modeling requires Need Analysis (Recruitment Analysis), System Design (System Design), Program Code Making (Coding), Implementation and Testing (Testing), and Support and Maintenance (Support and Maintenance). The results are in the form of an online recruitment system specifically for the personnel department, because personnel will have the information needed to be able to assess applicants before they are called to proceed to the direct interview session. In addition to simplifying the process of recruiting security guards, this system is also expected to make data collection of new security guards easier and integrated with the system, and suggestions for the future are that the system can be developed to recruit employees other than security guards.

\section{Pendahuluan}

Perkembangan zaman membuat segala sesuatu menjadi lebih mudah, tidak hanya memudahkan dalam pekerjaan, namun juga dapat mempermudah mendapatkan pekerjaan. Informasi didapatkan dari 
pengolahan suatu sistem informasi, dan teknologi menghasilkan peningkatan yang cukup besar terhadap informasi mengenai pencari pekerjaan. Penelitian yang dilakukan oleh Pin et al (2001) yang dituliskan dalam jurnal JIBEKA volume 7 No 3 pada agustus 2013, di antara 167 organisasi dari berbagai negara di Eropa, ditemukan bahwa $83 \%$ dari organisasi dalam penelitian mereka memiliki website perusahaan[1]. Karena perkembangan yang disebutkan di atas, penggunaan teknologi dalam proses perekrutan, menyebabkan munculnya e-rekrutmen, juga disebut rekrutmen online, e-recruitment, cybercruiting, rekrutmen berbasis web, atau merekrut dengan internet.

Oleh karena itu, pada kasus ini PT. Bravo Security Indonesia sebagai perusahaan penyalur tenaga kerja keamanan atau satpam membutuhkan sebuah sistem untuk dapat merekrut calon satpam baru, karena perusahaan ini sudah memiliki lebih dari 2500 personil satpam dan masih membutuhkan banyak satpam agar dapat di tugaskan ke mitra bisnis dari perusahaan tersebut, karna jika masih menggunakan rekrutmen manual maka akan membutuhkan banyak waktu yang tidak efektif dan efesien agar mendapatkan calon satpam terbaik yang sesuai dengan kriteria yang perusahaan butuhkan.

\section{Landasan Teori Sistem Informasi}

A. Kadir memaparkan bahwa sistem informasi merupakan suatu rangkaian proses dari pengumpulan data-data yang dikelompokan, lalu akan diproses menjadi sebuah informasi yang dapat digunakaan oleh pemakai atau yang membutuhkan informasi tersebut.

Sistem informasi dalam suatu organisasi dapat dikatakan sebagai suatu sistem yang menyediakan informasi bagi semua tingkatan dalam organisasi tersebut kapan saja diperlukan. Sistem ini menyimpan, mengambil, mengubah, mengolah dan mengkomunikasikan informasi yang diterima dengan menggunakan sistem informasi atau peralatan sistem lainnya.

\section{E-Recruitment}

Rahmawati memaparkan bahwa E-Recruitment adalah suatu proses rekrut untuk pekerjaan dan pemrosesan sistem secara online bagi perusahaan untuk mengiklankan lowongan pekerjaan mereka dan bagi para pencari pekerjaan dapat memasukkan lamaran mereka lewat internet. Dengan sistem $E$ Recruitment, persyaratan kerja, pengurutan daftar pekerja dan perekrutan pekerja menjadi lebih mudah bagi perusahaan atau organisasi.

Jadi dapat disimpulkan bahwa e-recruitment adalah proses rekrut pegawai atau pekerja yang dilakukan menggunakan sistem informasi dan juga internet agar dapat membantu proses bisnis perusahaan menjadi lebih mudah.

\section{SDLC}

Menurut Rosa dan Shalahuddin SDLC yang merupakan salah satu metodologi penelitian, memiliki singkatan dari Software Development Life Cycle yang merupakan sebuah proses atau tahapan yang digunakan untuk mengembangkan suatu sistem informasi dengan menggunakan beberapa model. Jika kupu-kupu memiliki proses metamorfosis agar bisa menjadi kupu-kupu yang indah, maka begitu juga dengan pengembangan sistem informasi, memerlukan tahapan-tahapan agar dapat mengembangkan sistem informasi yang berkualitas.

\section{Model Waterfall}

Menurut Rosa dan Shalahuddin "model SDLC air terjun (waterfall) sering juga disebut model seesensial linier (sequential linear) atau alur hidup klasik (classic life cycle)."

Menurut Pressman (2012) yang dimaksud metode air terjun atau yang sering disebut metode waterfall sering dinamakan siklus hidup klasik (classic life cycle), dimana hal ini menggambarkan pendekatan metodologi yang sistematis dan juga berurutan pada pengembangan perangkat lunak, dimulai dengan spesifikasi kebutuhan pengguna lalu berlanjut melalui tahapan-tahapan perencanaan ( $p l a n i n g$ ), permodelan (modeling), konstruksi (construction), serta penyerahan sistem ke para pelanggan/pengguna (deployment), yang diakhiri dengan dukungan pada perangkat lunak lengkap yang dihasilkan. 


\section{PHP}

Menurut Rahadyan PHP (Hypertext Preprocessor) adalah bahasa pemrograman berbasis web yang bekerja di server. Karena bekerja di sisi server maka kode sumber (source code) file tidak dapat dilihat di sisi client. Banyak juga yang bertanya apakah perbedaan PHP dengan HTML? Perbedaannya adalah PHP digunakan untuk membangun web dinamis sedangkan HTML hanya untuk membangun web statis.

Jadi bisa diartikan bahwa PHP adalah bahasa pemrograman yang digunakan untuk membuat sebuah web agar lebih dinamis, user Friendly dan lebih menarik lagi, sedangkan jika hanya menggunakan HTML maka hanya akan menjadi web statis.

\section{Basis Data}

Menurut buku yang ditulis oleh Rosa dan Shalahudding basis data atau database merupakan sistem yang terkomputerisasi yang tujuan utamanya adalah untuk memelihara data yang sudah diolah atau informasi dan membuat informasi tersedia disaat dibutuhkan[5].

Pada intinya basis data adalah media untuk menyimpan data agar dapat diakses dengan cepat dan juga mudah dan sistem informasi tidak bisa dipisahkan dengan kebutuhan akan basis data apa pun bentuknya, bisa dalam bentuk file teks ataupun Database Management System (DBMS).

\section{Metodologi Penelitian Analisa Sistem Berjalan}

Setelah penulis melakukan observasi langsung dan analisa terhadap sistem yang berjalan di PT. Bravo Security Indonesia, terdapat kelebihan dan kekurangan terhadap sistem yang berjalan :

Tabel 1 Kelebihan dan kekurangan sistem yang berjalan

\begin{tabular}{|c|c|}
\hline $\begin{array}{l}\text { Kelebihan sistem } \\
\text { yang berjalan }\end{array}$ & $\begin{array}{ll}\text { Kekurangan } & \text { sistem } \\
\text { yang berjalan } & \end{array}$ \\
\hline $\begin{array}{lr}\text { Bagian } & \text { personalia } \\
\text { atau rekrutmen } \\
\text { dapat menjelaskan } \\
\text { secara langsung } \\
\text { prosedur dan data } \\
\text { apa saja yang } \\
\text { dibutuhkan oleh } \\
\text { pelamar. }\end{array}$ & $\begin{array}{l}\text { Memakan waktu yang } \\
\text { lama bila ingin } \\
\text { bertemu dengan } \\
\text { pelamar, karena } \\
\text { harus menentukan } \\
\text { jadwal yang pas } \\
\text { untuk personalia dan } \\
\text { juga untuk pelamar. }\end{array}$ \\
\hline $\begin{array}{l}\text { Pelamar dapat } \\
\text { berinteraksi secara } \\
\text { langsung dengan } \\
\text { bagian personalia } \\
\text { atau rekrutmen } \\
\text { mengenai } \\
\text { perusahaan dan } \\
\text { berbagai hal. }\end{array}$ & $\begin{array}{l}\text { Pencarian satpam } \\
\text { baru menjadi lebih } \\
\text { lama karena tidak } \\
\text { semua yang melamar } \\
\text { pekerjaan memenuhi } \\
\text { syarat-syarat yang } \\
\text { sudah ditentukan di } \\
\text { awal dan hal tersebut } \\
\text { sangat membuang- } \\
\text { buang waktu dan } \\
\text { tenaga. }\end{array}$ \\
\hline & $\begin{array}{l}\text { Biaya operasional } \\
\text { yang dikeluarkan juga } \\
\text { menjadi lebih banyak } \\
\text { seperti biaya telepon. }\end{array}$ \\
\hline
\end{tabular}




\section{Analisa Kebutuhkan Sistem}

Dalam perancangan sistem rekrutmen online ini dibutuhkan sebuah analisa kebutuhan agar sistem dapat berfungsi dengan baik dan sesuai dengan keperluan perusahaan. Data didapat dari wawancara dan hasil observasi langsung ke perusahaan. Agar mendapatkan calon satpam yang memenuhi standar perusahaan maka dibuatlah Sistem rekrutmen online sebagai alat bantu untuk departemen personalia.

Perancangan sistem rekrutmen online ini memiliki fungsi-fungsi yang dapat dilakukan, di antaranya:

1. Memasukkan data diri pelamar.

Fungsi ini berguna untuk input data diri, pendidikan terakhir yang diambil oleh pelamar, pengalaman pekerjaan terakhir dan juga foto-foto yang diperlukan untuk proses rekrutmen.

2. Menampilkan data lengkap pelamar.

Fungsi ini dilakukan oleh departemen personalia agar dapat melihat data pelamar secara rinci dan juga lengkap, untuk membantu memilih pelamar yang lolos ke tahap wawancara.

3. Mengubah Status pelamar.

Fungsi ini juga dilakukan oleh departemen personalia agar dapat mengubah status rekrutmen, apakah pelamar berhasil diterima atau gagal dalam rekrutmen.

4. Menampilkan hasil rekrutmen.

Fungsi ini adalah fungsi yang dapat menampilkan informasi tentang hasil perekrutan dan juga tanggal untuk wawancara.

5. Menampilkan informasi tentang rekrutmen

Fungsi ini adalah fungsi yang dapat menampilkan segala informasi mengenai kebutuhan rekrutmen dan juga syarat-syarat yang dibutuhkan agar lolos ke tahap wawancara.

\section{Rancangan Sistem Baru}

Setelah penulis menganalisa sistem atau proses bisnis yang sedang berjalan di perusahaan tersebut, maka dari hasil analisa digunakan untuk membangun sebuah sistem rekrutmen online satpam yang akan mempermudah proses rekrutmen satpam di perusahaan PT. Bravo Security Indonesia.

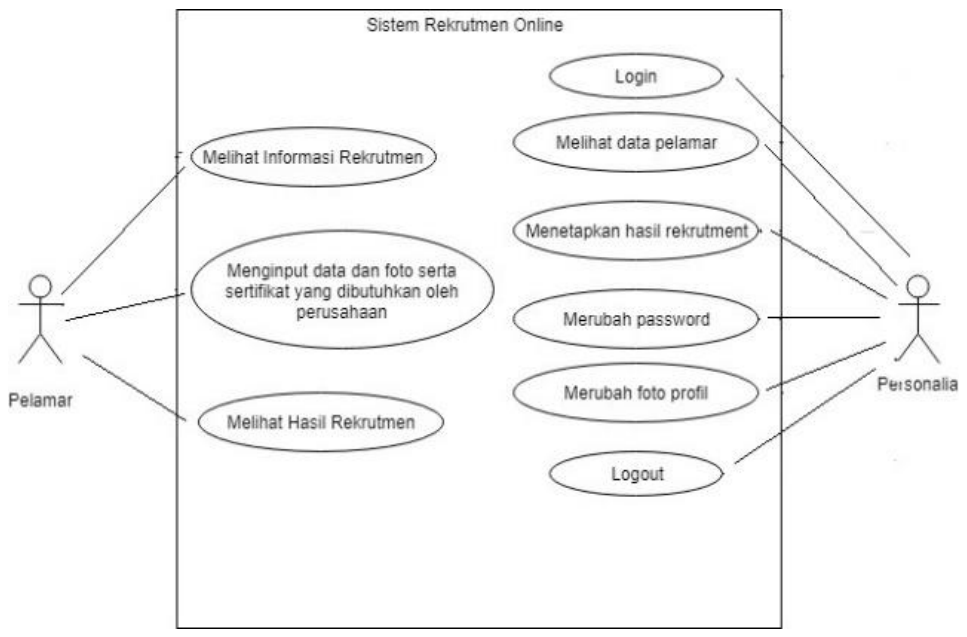

Gambar 1 Use Case Sistem yang diusulkan

Gambar di atas merupakan usecase sistem rekrutmen online yang menjelaskan hubungan pelamar dan personalia dengan sistem yang akan diusulkan ke perusahaan. Menjelaskan di mana pelamar memulai dengan melihat informasi yang diberikan di dalam sistem dan jika pelamar tertarik maka pelamar dapat input data diri, pendidikan terakhir dan juga pengalaman bekerja terakhir yang dimiliki oleh pelamar, dan pelamar juga bisa upload foto diri, ijazah dan juga sertifikat pendukung lainya.

Pada gambar di atas juga dijelaskan bahwa pelamar dapat melihat informasi mengenai hasil lamaran dan juga informasi tentang wawancara yang akan dilakukan oleh perusahaan. 
Sedangkan pada bagian personalia menjelaskan hubungan antara departemen personalia dengan sistem rekrutmen online yang akan diusulkan ke perusahaan. Pihak personalia dapat memberikan tentang informasi apa saja yang dibutuhkan oleh pelamar begitu juga informasi tentang hasil rekrutan dan informasi tentang interview yang akan dilakukan perusahaan. Personalia juga dapat melihat data-data secara detail yang telah di masukan oleh pelamar dan juga mengedit data yang telah dimasukkan oleh pelamar.

\section{Activity Diagram}

Dalam buku yang ditulis oleh Rosa dan Shalahuddin (2014) dikatakan "Diagram aktivitas atau activity diagram menggambarkan workflow (aliran kerja) atau aktivitas dari sebuah sistem atau proses bisnis atau menu yang ada". Yang digambarkan adalah aktivitas sistem, bukan apa yang dilakukan aktor.

\section{Activity Diagram Login}

Agar personalia bisa masuk ke dalam halaman utama sistem rekrutmen online maka personalia harus input username dan password dengan benar, dan aplikasi akan melakukan verifikasi ke basis data apakah sudah benar atau belum, dan jika salah maka personalia akan mendapatkan pesan gagal login dan harus memasukkan data yang benar jika ingin masuk ke dalam sistem rekrutmen online.

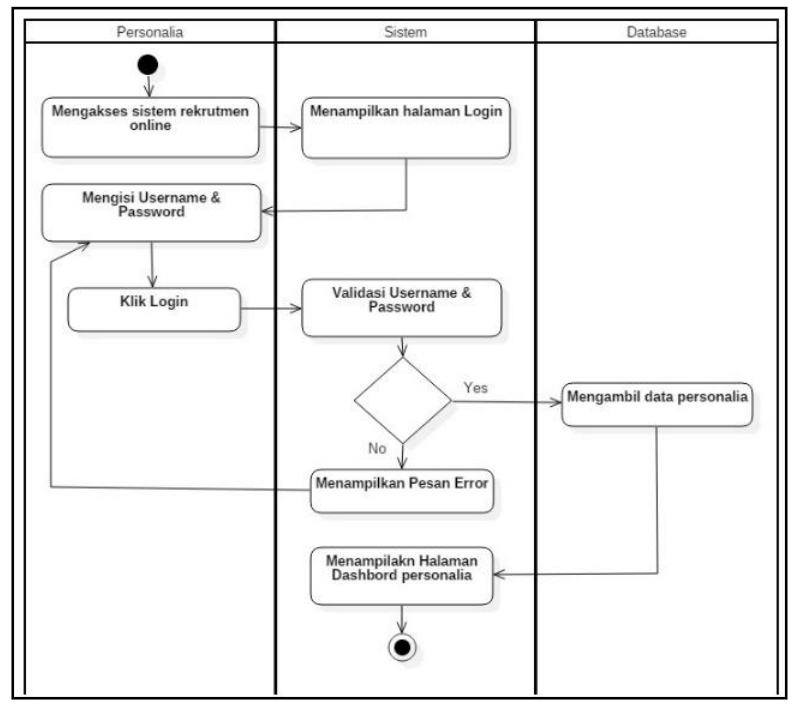

Gambar 2 Activity Diagram Login Personalia

\section{Activity Diagram Lihat Data Pelamar}

Apabila personalia telah masuk ke dalam halaman utama sistem rekrutmen maka personalia bisa melihat data-data dari semua pelamar yang telah input datanya. Data-data yang telah dimasukkan dapat dilihat secara detail oleh pihak personalia, dan dari data-data tersebut dapat membantu manajemen pihak personalia untuk memilih pelamar mana yang lolos ke tahap wawancara. Untuk lebih jelasnya akan dijelaskan pada gambar di bawah ini. 


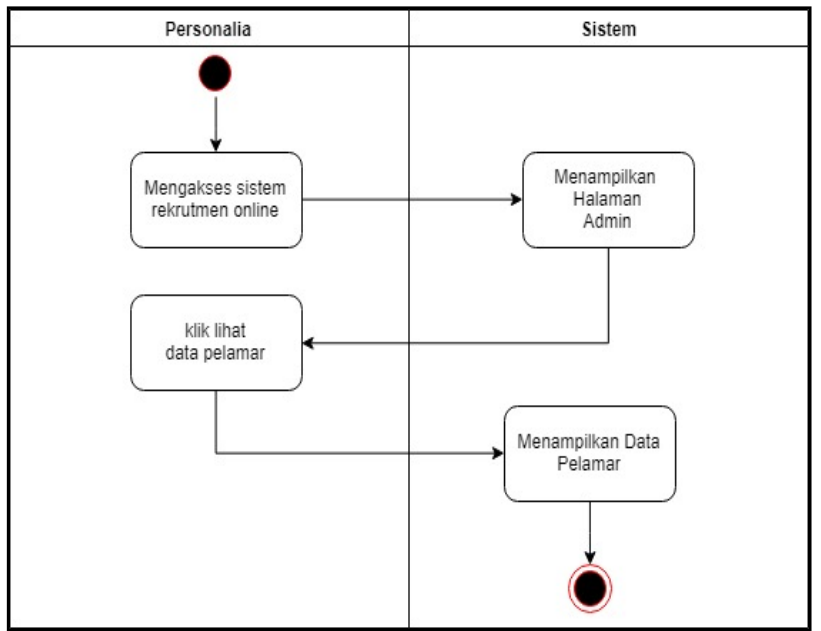

Gambar 3 Activity Diagram Lihat Data Pelamar

\section{Activity Diagram Mengubah Status Penerimaan}

Fungsi lain dari sistem rekrutmen ini adalah pihak personalia dapat mengubah status apakah pelamar diterima oleh perusahaan untuk melakukan interview atau pelamar ditolak. Fungsi ini merupakan salah satu fungsi yang sangat dibutuhkan oleh sistem rekrutmen online ini, oleh karena itu fungsi ini dikhususkan hanya untuk personalia.

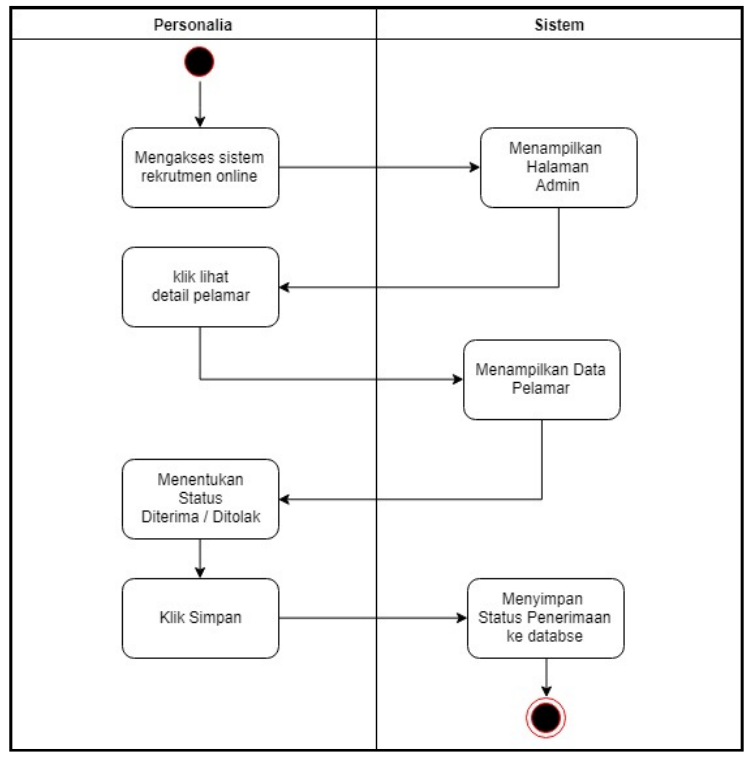

Gambar 4 Activity Diagram Update Status Penerimaan

\section{Class Diagram}

Rosa dan Shalahuddin (2014) Memaparkan bahwa kelas-kelas yang ada pada struktur harus dapat melakukan fungsi-fungsi sesuai dengan kebutuhan sistem agar pembuat sistem atau yang sering disebut programmer dapat membuat sesuai apa yang dirancang[5], berikut adalah diagram kelas yang dirancang: 


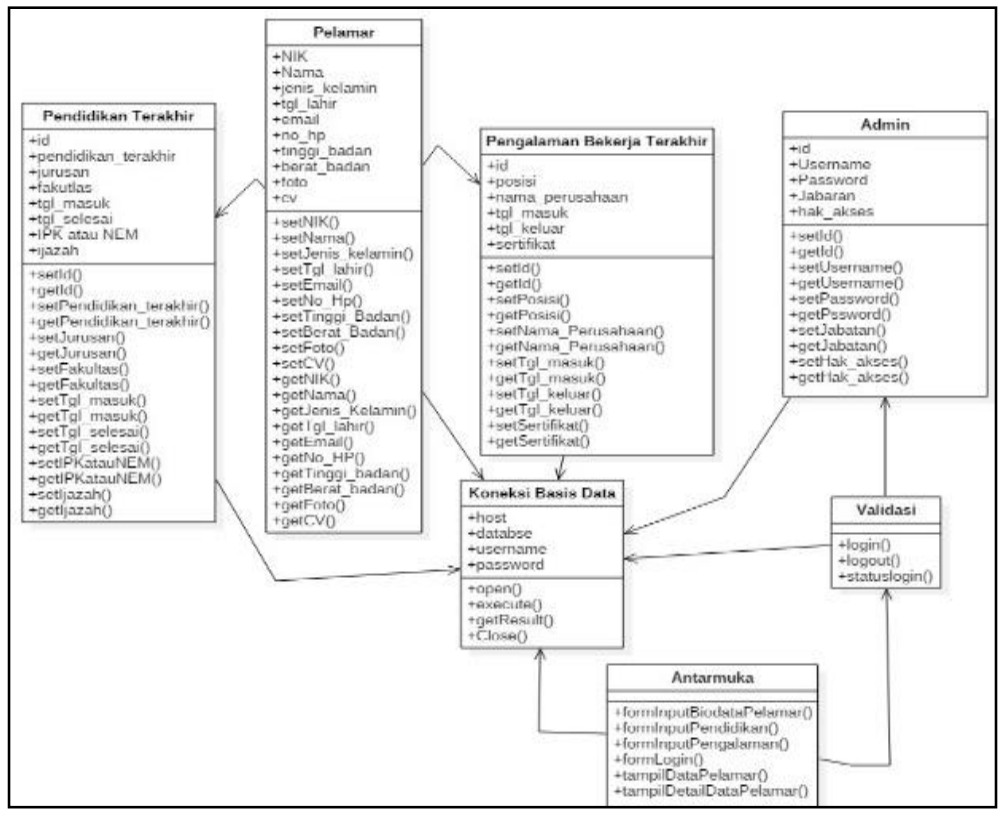

Gambar 5 Class Diagram Perancangan Sistem

\section{Hasil dan Perancangan}

\section{Hasil Perancangan Tampilan Informasi}

Halaman pertama yang ditujukan untuk pelamar adalah halaman untuk menampilkan informasi tentang PT. Bravo Security Indonesia dan juga informasi untuk syarat-syarat rekrutmen, seperti yang ada pada gambar berikut:

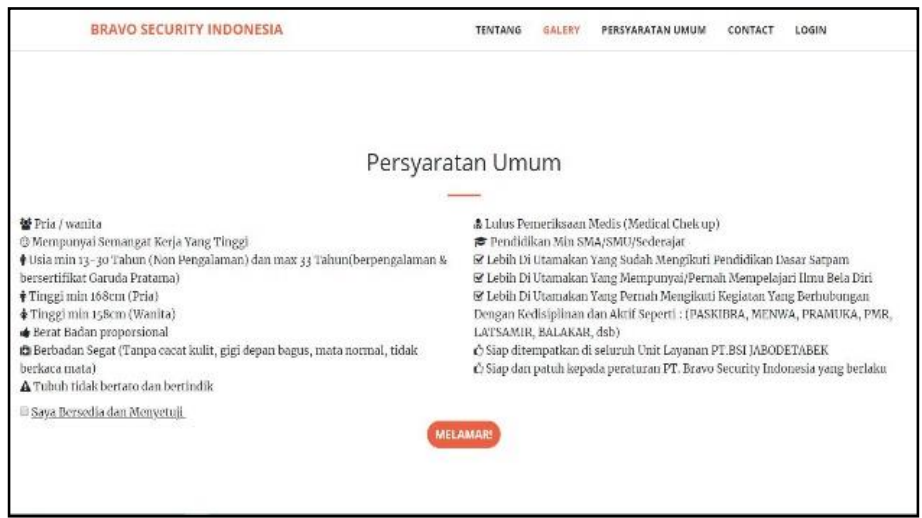

Gambar 6 Tampilan syarat Recruitment

\section{Halaman Mengisi Data diri}

Tahap selanjutnya ialah pelamar input semua data yang diperlukan oleh perusahaan agar dapat di review apakah cocok dengan kebutuhan PT. Bravo Security Indonesia. Pelamar akan disediakan form untuk mengisi data diri dan mengunggah foto seperti yang ada pada gambar di bawah. 


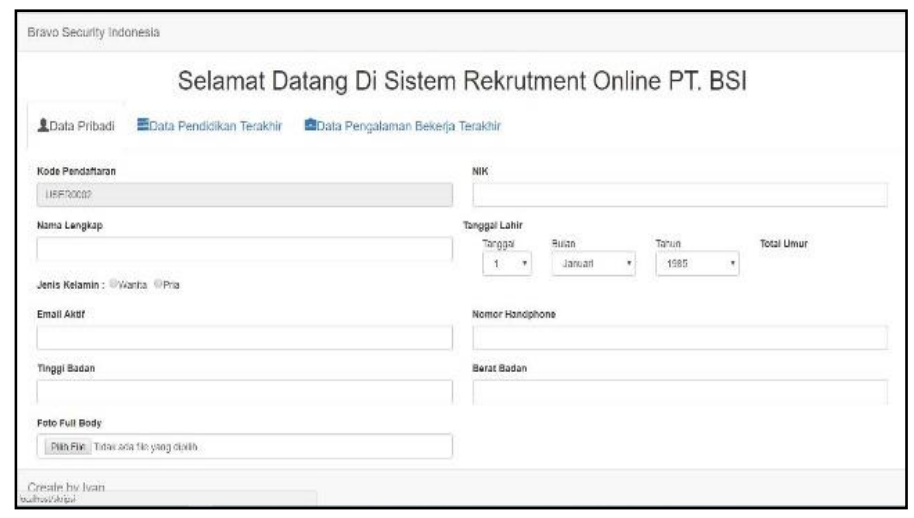

Gambar 7 Halaman mengisi data diri

\section{Halaman Pendidikan Terakhir}

Setelah selesai dengan mengisi data-data pribadi, maka selanjutnya pelamar harus mengisi data riwayat pendidikan terakhir dan juga mengunggah foto ijazah yang di dapatkan.

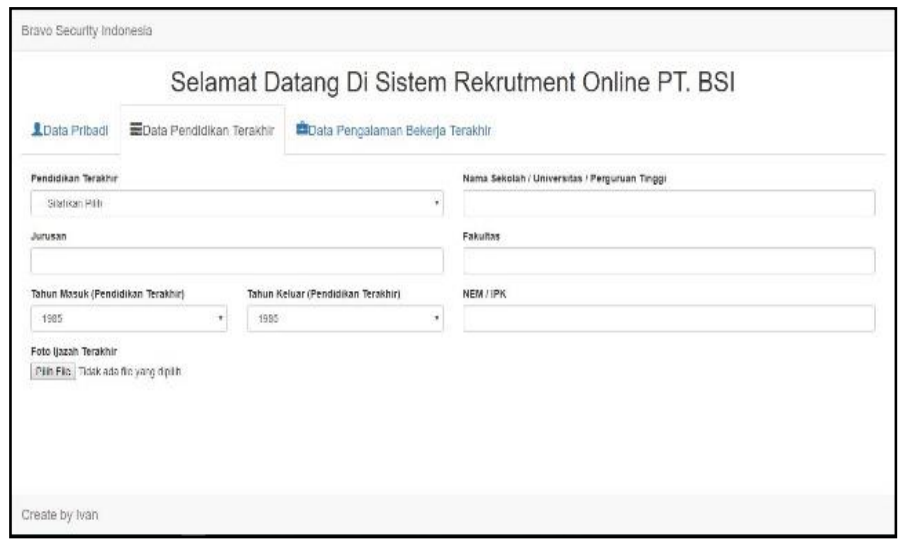

Gambar 8 Halaman Mengisi Pendidikan Terakhir

\section{Halaman Pekerjaan Terakhir}

Jika pelamar sudah mengisi data diri dan juga data pendidikan terakhir, maka selanjutnya pelamar akan disediakan form atau tampilan untuk mengisi data riwayat pekerjaan terakhir dari si pelamar. Serta pada halaman ini pelamar bisa mengunggah sertifikat pendukung yang berhubungan dengan rekrutmen satpam pada PT. Bravo Security Indonesia.

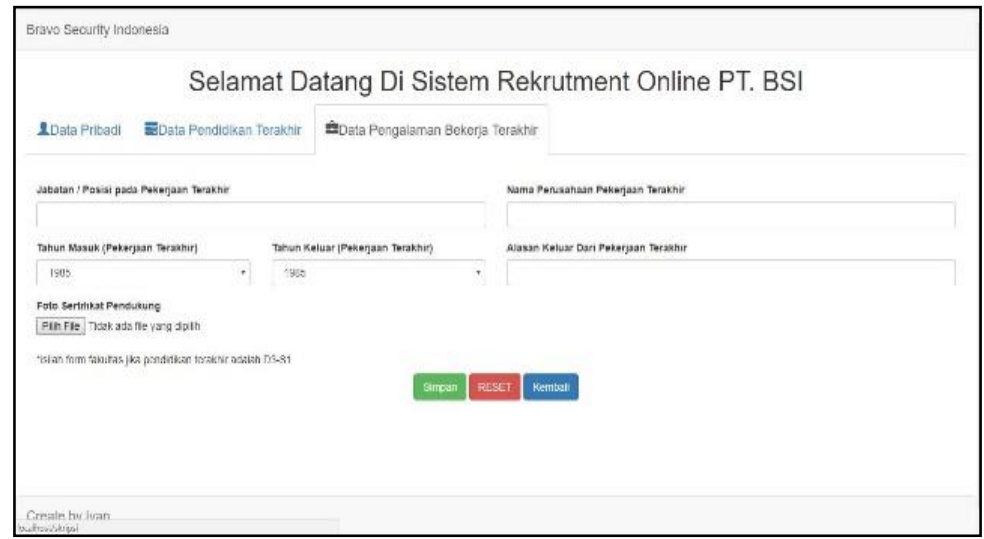

Gambar 9 Halaman Mengisi Pekerjaan Terakhir 


\section{Halaman Lihat Hasil Rekrutmen}

Jika personalia sudah menetapkan hasil dari rekrutmen tahap ini, maka pada sistem akan disediakan sebuah halaman agar pelamar dapat melihat daftar nama-nama yang lolos ke tahap selanjut nya, dan dengan mengetahui hal tersebut pelamar dapat menyiapkan segala sesuatu yang dibutuhkan untuk selanjutnya.

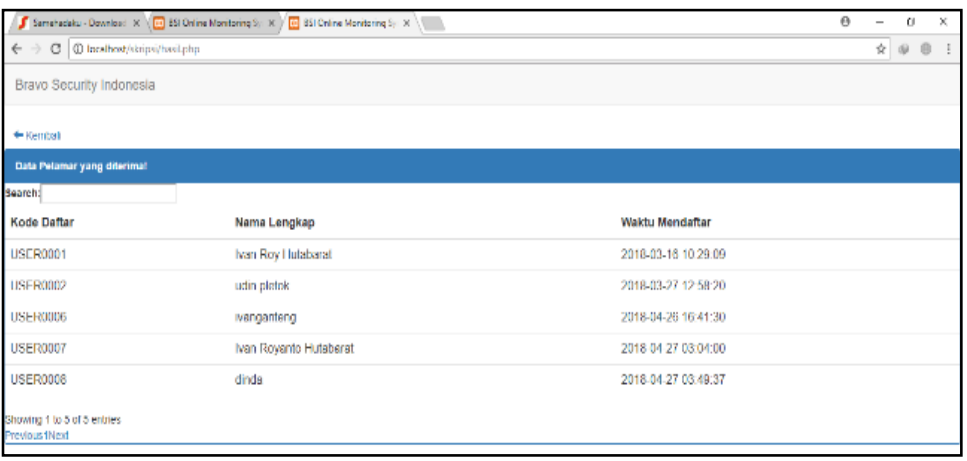

Gambar 10 Tampilan Lihat Hasil

\section{Halaman Tampil Detail Data diri}

Salah satu fungsi penting dari sistem rekrutmen online ini adalah, dapat menampilkan seluruh data yang di masukan oleh pelamar, sehingga dapat membantu bagian personalia untuk meriview apakah pelamar akan diterima atau tidak.

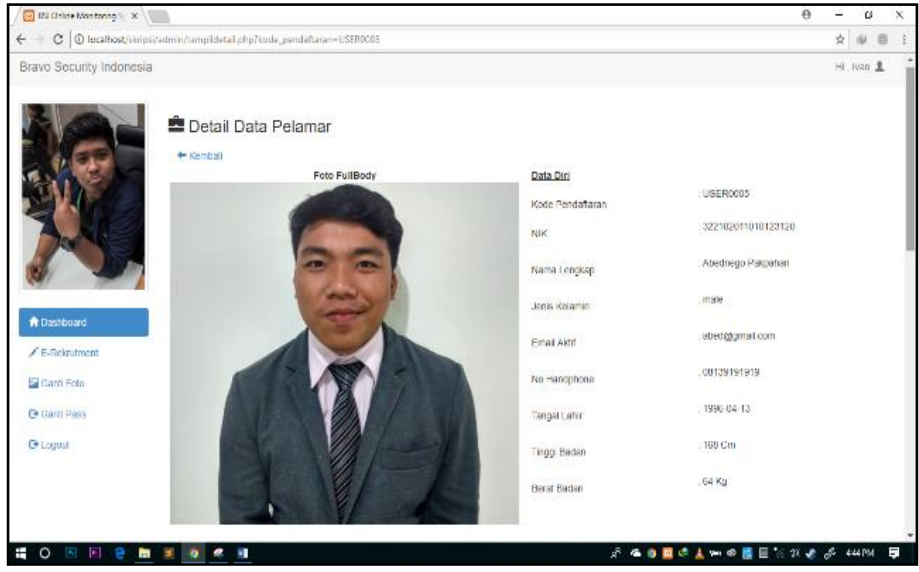

Gambar 11 Tampilan Detail Datadiri

\section{Detail Pendidikan Terakhir}

Selanjutnya adalah detail riwayat pendidikan terakhir yang diambil atau dilalui oleh pelamar. Data yang dibutuhkan antara lain seperti pendidikan terakhir, tempat, jurusan atau fakultas (jika pendidikan minimal D3) dan juga nilai akhir yang didapat oleh si pelamar 


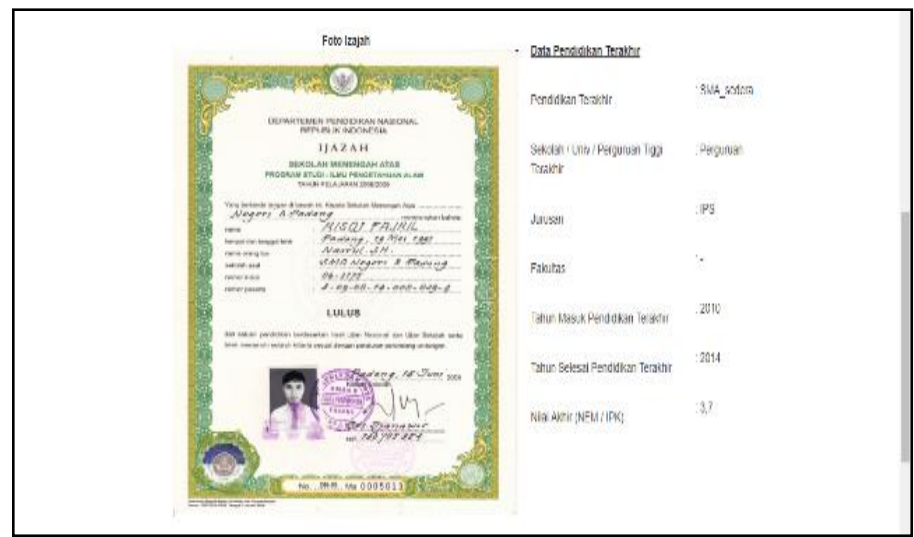

Gambar 12 Tampilan Detail Pendidikan Terakhir

\section{Detail Pekerjaan Terakhir}

Yang terakhir dari menu tampilan detail adalah data detail riwayat pekerjaan terakhir yang pernah dilakukan oleh pelamar, jika pelamar sebelumnya adalah pengangguran maka data ini akan kosong, namun jika pelamar memiliki pekerjaan sebelumnya dan sertifikat pendukung maka pelamar harus mengisinya sesuai dengan apa yang di perlukan oleh perusahaan untuk dapat menilai atau review pelamar tersebut.

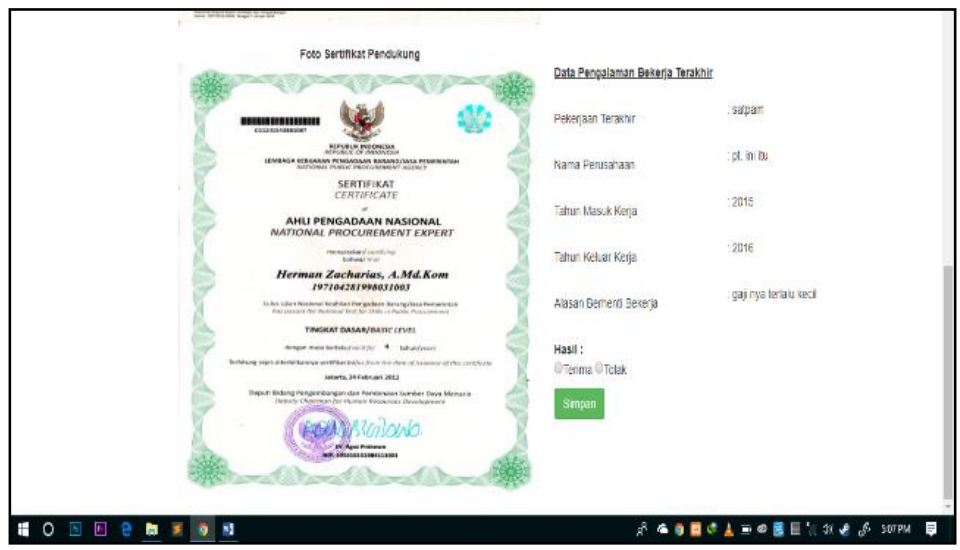

Gambar 13 Tampilan Detail Pekerjaan Terakhir

\section{Pengujian Sistem}

Pengujian sistem atau testing bertujuan untuk mengetahui apakah sistem yang dirancang sudah sesuai dengan yang diharapkan. Sistem yang telah dirancang akan di testing untuk mengetahui apakah fungsi yang ada sudah sesuai yang diharapkan serta mengetahui kelemahan dari fungsi yang ada. Metode yang akan digunakan oleh penulis adalah metode yang disebut black box testing.

\section{Hasil Pengujian Sistem} black box :

Setelah menentukan tahapan atau langkah-langkah pengujian, berikut adalah hasil dari pengujian

Tabel 2 Hasil Pengujian Sistem

\begin{tabular}{|l|l|l|}
\hline Komponen Sistem yang Di Uji & Hasil yang di Harapkan & Hasil Pengujian \\
\hline \multirow{4}{*}{$\begin{array}{l}\text { Halaman Persetujuan Syarat \& pengguna mengeklik } \\
\text { Ketentuan Rekrutmen }\end{array}$} & $\begin{array}{l}\text { Saat } \sqrt{ } \text { Diterima } \\
\text { [ ] Ditolak }\end{array}$ \\
\cline { 2 - 3 } & $\begin{array}{l}\text { Saat pengetujuan baru bisa lanjut } \\
\text { syarat dan ketentuan maka tidak } \\
\text { bisa lanjut }\end{array}$ & $\begin{array}{l}\text { [ } \sqrt{ } \text { ]Diterima } \\
\text { [ ] Ditolak }\end{array}$ \\
\hline
\end{tabular}




\begin{tabular}{|c|c|c|}
\hline Komponen Sistem yang Di Uji & Hasil yang di Harapkan & Hasil Pengujian \\
\hline \multirow{2}{*}{ Halaman Pengisian Data-data } & $\begin{array}{l}\text { Saat pengguna memasukkan semua } \\
\text { data dengan benar, maka akan } \\
\text { masuk disimpan ke basis data }\end{array}$ & $\begin{array}{l}{[\checkmark \text { ]Diterima }} \\
{[\quad] \text { Ditolak }}\end{array}$ \\
\hline & $\begin{array}{l}\text { Saat pengguna memasukkan } \\
\text { sebagian data, maka akan } \\
\text { diberitahukan kesalahan pada sistem }\end{array}$ & $\begin{array}{l}{[\checkmark \text { ]Diterima }} \\
{[\text { ] Ditolak }}\end{array}$ \\
\hline \multirow{2}{*}{ Halaman Login } & $\begin{array}{l}\text { Saat pengguna memasukkan data } \\
\text { dengan benar, maka akan masuk ke } \\
\text { halaman home admin/personalia }\end{array}$ & $\begin{array}{l}{[\checkmark \text { ]Diterima }} \\
{[\text { ] Ditolak }}\end{array}$ \\
\hline & $\begin{array}{l}\text { Saat pengguna memasukkan data, } \\
\text { maka akan diberitahukan kesalahan } \\
\text { sistem }\end{array}$ & $\begin{array}{l}{[\checkmark \text { Diterima }} \\
{[\text { ] Ditolak }}\end{array}$ \\
\hline Halaman Data Pelamar & $\begin{array}{l}\text { Saat personalia / admin membuka } \\
\text { halaman data pelamar, maka akan } \\
\text { menampilkan pelamar sesuai dengan } \\
\text { status penerimaannya }\end{array}$ & $\begin{array}{l}{[\checkmark \text { ]Diterima }} \\
{[\quad] \text { Ditolak }}\end{array}$ \\
\hline \multirow[t]{2}{*}{ Halaman Data Detail Pelamar } & $\begin{array}{l}\text { Saat pelamar mengeklik tombol } \\
\text { detail maka akan langsung dialihkan } \\
\text { ke detail pelamar }\end{array}$ & $\begin{array}{l}{[\checkmark \text { ]Diterima }} \\
{[\text { ] Ditolak }}\end{array}$ \\
\hline & $\begin{array}{l}\text { Akan menampilkan semua data yang } \\
\text { dimasukkan oleh pelamar yang } \\
\text { dipilih dari database }\end{array}$ & $\begin{array}{l}{[\checkmark \text { Diterima }} \\
{[\text { ] Ditolak }}\end{array}$ \\
\hline Status Rekrutmen & $\begin{array}{l}\text { Saat pelamar melihat detail pelamar, } \\
\text { maka pelamar akan disediakan opsin } \\
\text { untuk status rekrutmen, jika sudah } \\
\text { ditetapkan, maka akan dikategorikan } \\
\text { sesuai status }\end{array}$ & $\begin{array}{l}{[\checkmark \text { ]Diterima }} \\
{[\text { ] Ditolak }}\end{array}$ \\
\hline \multirow[t]{2}{*}{ Halaman Ganti Foto Profil } & $\begin{array}{l}\text { Saat personalia / admin membuka } \\
\text { halaman ganti foto profil, maka } \\
\text { sistem akan menyediakan form } \\
\text { untuk memilih gambar }\end{array}$ & $\begin{array}{l}{[\checkmark \text { Diterima }} \\
{[\text { ] Ditolak }}\end{array}$ \\
\hline & $\begin{array}{l}\text { Setelah berhasil upload foto, maka } \\
\text { akan ada notifikasi berhasil dan jika } \\
\text { gagal maka akan ada notifikasi gagal }\end{array}$ & $\begin{array}{l}{[\checkmark \text { Diterima }} \\
{[\quad] \text { Ditolak }}\end{array}$ \\
\hline Halaman Ganti Password Profil & $\begin{array}{l}\text { Saat personalia / admin membuka } \\
\text { halaman ganti password, maka } \\
\text { sistem akan menyediakan form } \\
\text { untuk ganti password, dan akan } \\
\text { diubah di database }\end{array}$ & $\begin{array}{l}{[\checkmark \text { Diterima }} \\
{[\text { ] Ditolak }}\end{array}$ \\
\hline Sign Out & $\begin{array}{l}\text { Saat pelamar menekan tombol, } \\
\text { maka halaman akan langsung } \\
\text { dialihkan ke halaman login kembali }\end{array}$ & $\begin{array}{l}{[\checkmark \text { Diterima }} \\
{[\quad] \text { Ditolak }}\end{array}$ \\
\hline
\end{tabular}

Berdasarkan dari pengujian sistem menggunakan metode Black Box, maka penulis dapat menyimpulkan bahwa sistem sudah berjalan dengan baik sesuai dengan fungsi yang diharapkan dan mengeluarkan informasi yang sesuai dengan data yang ada atau yang tersimpan di dalam basis data.

Diharapkan dengan dilakukannya pengujian terhadap sistem rekrutment satpam pada PT. Bravo Security Indonesia secara online, penulis dapat melihat serta mengetahui apakah sistem derdapat bugs 
atau erro, dan jika terdapat bugs dan juga error di dalam sistem, maka penulisa dapat melakukan perbaikan serta maintenance terhadap sistem tersebut.

\section{Kesimpulan dan Saran \\ Kesimpulan}

Berdasarkan penelitian yang telah dilakukan terhadap sistem, maka kesimpulan yang didapat dari perancangan sistem ini adalah sebagai berikut:

1. Sistem rekrutmen online atau E-Recruitment ini dapat membantu departemen personalia dalam mengumpulkan informasi dari pelamar serta membantu personalia untuk review apakah pelamar akan lanjut ke tahap interview atau tidak.

2. Pelamar bisa dengan mudah mendaftar sebagai satpam dengan bantuan sistem ini karena sistem ini berbasis website online yang dapat diakses kapan saja, di mana saja selagi ada jaringan internet.

\section{Saran}

Berdasarkan kesimpulan yang telah dipaparkan di atas, maka penulis menemukan beberapa hal yang dapat dikembangkan yaitu:

1. Pengembangan sistem agar tidak hanya untuk penerimaan satpam, namun dapat digunakan untuk rekrutmen pada bagian lain seperti rekrutmen untuk departemen IT, departemen personalia, akuntansi serta bagian-bagian lain dalam perusahaan.

2. Agar sistem berjalan dengan baik, penulis menyarankan untuk perusahaan agar menggunakan basis data yang besar serta maintenance berkala agar sistem bisa berjalan dengan optimal.

3. Penulis berpendapat bahwa, sistem ini sebaiknya di integrasikan dengan basis data pada PT. Bravo Security Indonesia, agar departemen personalia dapat secepatnya menggunakan sistem ini dan memudahkan pekerjaan nya.

\section{Referensi}

1. T, Septian.2013. Rekrutmen Online (E-Recruitment) Sebagai Suatu Inovasi Dalam Perekrutan Perusahaan. JIBEKA Volume 7 No 3, 54-59.

2. Galanaki, E. 2002, The Decision to Recruit Online: A Descriptive Study,Career Development International. 7, 4, $243-251$.

3. Kadir, A. (2013), Pengenalan Sistem Informasi Edisi Revisi. Yogyakarta: Andi Offsett.

4. Rahmawati, Windi Anisa. 2011. Rancang bangun E-Recruitment Pegawai pada Wakaf Center. Jakarta. Universitas Islam Negri Syarif Hidayatullah.

5. Rosa. A.S., dan Shalahuddin. M, "Rekayasa Perangkat Lunak", 2nd ed, Bandung: Informatika, 2014.

6. Pressman, Roger S. 2012. Rekayasa Perangkat Lunak - Buku Satu, Pendekatan Praktisi (Edisi 7). Yogyakarta: Andi.

7. Rahadyan, Dewan. 2014. Sistem Informasi Pendukung Keputusan Parawisata berbasis web. Universitas Komputer Indonesia. 